\title{
Biomass as a raw material for energy production
}

\section{Tsatiris Michael and Kyriaki Kitikidou}

Department of Forestry and Management of the Environment and Natural Resources. Democritus University of Thrace. Orestiada 68200. Greece. Email: kkitikid@fmenr.duth.gr.

\begin{abstract}
In this paper, the meaning of biomass is defined and it is explained why it is a potential source of energy. The utilization of biomass as an energy source is based on heat energy production during its combustion. The solar energy captured and stored by plants is released in the form of heat energy during the biomass combustion. The variables that affect the energy value (calorific value) of forest biomass involve the chemical composition, percentage of extractives, moisture content, ash content and density. Softwoods generally contain more energy than hardwoods on a dry weight basis, due to higher lignin content plus the presence of more resinous extractives. Lastly, the advantages and disadvantages of biomass as an energy source are analyzed: biomass is renewable and eco-friendly, but its efficiency is low.
\end{abstract}

Keywords: Biomass; Forests; Energy Resources; Energy value; Calorific value.
Received

October 25, 2016

Accepted

November 24, 2016

Released

December 31, 2016

Open Acess Full Text Article

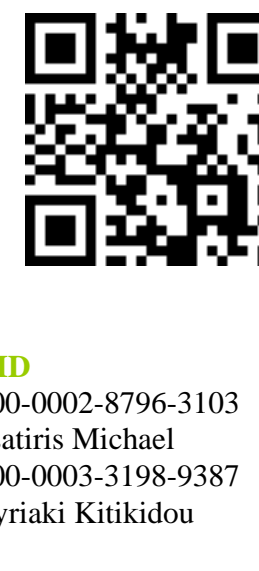

\section{Introduction}

The term biomass refers to the living materials in the biosphere and their refuse and waste products. It is defined as any organic matter that is available on a renewable basis, including agricultural crops and agricultural wastes and residues, wood and wood wastes and residues, animal wastes, municipal wastes and aquatic plants (ASTM, 1981). Biomass is the result of photosynthesis. Photosynthesis is the process by which chlorophyllcontaining cells in green plants convert incident light to chemical energy and synthesize organic compounds from inorganic compounds, especially carbohydrates from carbon dioxide and water with the simultaneous release of oxygen (ASTM, 1981). The total balance of photosynthesis is expressed by the reaction:

$$
\begin{array}{r}
6 \mathrm{H}_{2} \mathrm{O}+6 \mathrm{CO}_{2}+\text { photons } \rightarrow \mathrm{C}_{6} \mathrm{H}_{12} \mathrm{O}_{6}+6 \mathrm{O}_{2} \\
\text { Solar energy is transformed by }
\end{array}
$$
plants with a course of procedures. The basic raw materials for this are water and carbon dioxide that abound in nature. Energy comes from the visible spectrum of solar radiation. The fundamental reactions take place in chlorophyll which captures the photons and activates the photosynthesis 
process (Apostolakis et al., 1987; Sooter, 1992). The process of photosynthesis embodies the two most important reactions in life. The first one is the water-splitting reaction which evolves oxygen as a by-product; all life depends on this reaction. Secondly is the fixation of carbon dioxide to organic compounds; all our food and fuel is derived from this $\mathrm{CO}_{2}$ fixation from the atmosphere (Hall, 1983). These compounds contribute to the formation and growth of various plant organs and lead to biomass production. Also, inorganic elements as well as the proper temperature conditions for each plant species must coexist.

Consequently, it could be said that plants constitute a solar energy conversion system, since this is what photosynthesis is all about. Thus, everything which has been derived from the process of photosynthesis (biomass) is a potential source of energy.

\section{Utilization of biomass as an energy source}

The utilization of biomass as an energy source is based on heat energy production during its combustion (the solar energy captured and stored by plants is released in the form of heat energy during the biomass combustion). Combustion is the rapid chemical combination of oxygen with the elements of fuel that will burn with the release of heat energy. The maximum amount of heat energy which is produced when $1 \mathrm{~g}$ or $1 \mathrm{~kg}$ of dry mass is completely combusted is called calorific value or heating value and it is usually expressed in $\mathrm{kcal} / \mathrm{kg}$ of absolutely dry mass (Tsoumis and Philippou, 1982).

The major combustible elements of lignocellulosic materials are carbon and hydrogen. Complete oxidation of these elements gives $\mathrm{CO}_{2}, \mathrm{H}_{2} \mathrm{O}$ and heat energy as follows (Philippou, 1981; Tsoumis and Philippou, 1982):

$$
\begin{gathered}
\mathrm{C}+\mathrm{O}_{2} \rightarrow \mathrm{CO}_{2}+7,840 \mathrm{kcal} / \mathrm{kg} \text { of } \mathrm{C} \\
\mathrm{H}_{2}+1 / 2 \mathrm{O}_{2} \rightarrow \mathrm{H}_{2} \mathrm{O}+34,000 \mathrm{kcal} / \mathrm{kg} \text { of } \mathrm{H}_{2}
\end{gathered}
$$

\section{Energy value of forest biomass and variables which affect it}

The value of biomass as a source of energy is based on its chemical composition. Also, its energy value is affected by the existence of extractives, as for instance the pine resin (Tillman, 1978; Tsoumis and Philippou, 1982). Various biomass types (wood, bark, foliage and so on) vary in chemical composition and concomitantly in energy value. The different chemical compositions are responsible for varying heat contents among biomass fuels (Tillman, 1978). Forest biomass is composed of holocellulose (cellulose and hemicellulose), lignin and various extractives (Table 1).

Table 1. Chemical composition and calorific value of forest biomass.

\begin{tabular}{lcc}
\hline Chemical components & Percentage \% & Calorific value (kcal/kg) \\
\hline Cellulose & $30-55$ & $4,100-4,350$ \\
Hemicelluloses & $17-40$ & $4,100-4,350$ \\
Lignin & $16-35$ & $6,100-6,500$ \\
Extractives & $01-40$ & $4,100-9,150$ \\
Forest biomass & - & $3,960-6,289$ \\
\hline
\end{tabular}

Source: Philippou (1986).

The calorific value of holocellulose ranges from 4,100 to $4,350 \mathrm{kcal} / \mathrm{kg}$ of lignin from 6,100 to $6,500 \mathrm{kcal} / \mathrm{kg}$, and of extractives from 4,100 to $9,150 \mathrm{kcal} / \mathrm{kg}$. The percentage of the above chemical components differs among various forest species as well as among various parts (wood, bark, foliage, branches, tops) of the same tree (Philippou, 1982). Thus, the calorific value of various forest biomass 
types was found to range from 3,960 to 6,289 kcal/kg (Philippou, 1981, 1982, 1986).

Softwoods generally contain more energy than hardwoods on a dry weight basis due to higher lignin content plus the presence of more resinous extractives (Tillman, 1978). Lignin has higher calorific value $(6,100-6,500 \mathrm{kcal} / \mathrm{kg})$ than cellulose (4,100-4,350 kcal/kg) (Philippou, 1986). The calorific value of resin is high $(8,500$ $\mathrm{kcal} / \mathrm{kg}$ ) (Tsoumis and Philippou, 1982).

The mean calorific value of softwoods (29\% lignin on average, more resins) is about $4,900 \mathrm{kcal} / \mathrm{kg}$, whereas of hardwoods (22\% lignin on an average) is about 4,500 kcal/kg (Tillman, 1978; Philippou, 1986). Branches in both hardwoods and softwoods have higher calorific value $(4,665-4,954 \mathrm{kcal} / \mathrm{kg})$ than tree trunk $(4,500 \mathrm{kcal} / \mathrm{kg}$, on average) (Tsoumis and Philippou, 1982; Philippou, 1982). In softwoods, bark has higher mean calorific value $(5,073 \mathrm{kcal} / \mathrm{kg}$ on average) than wood $(4,900 \mathrm{kcal} / \mathrm{kg}$, on average), whereas in hardwoods occurs the opposite (Philippou, 1982; Tsoumis and Philippou, 1982). In general, the calorific value of a material is related to the contained percentage of carbon and hydrogen (Table 2). The low calorific value of lignocellulosic material (carbon $50 \pm 2 \%$, oxygen $40 \pm 3 \%$ and hydrogen $6 \pm 1 \%$ ) in relation to the other fuels (coal, oil) is due to the high percentage of oxygen in its molecular structure (Tillman, 1978; Philippou, 1981, 1986). Beyond the chemical composition and percentage of extractives, calorific value of forest biomass depends on the moisture content, ash and density (Tillman, 1978; Tsoumis and Philippou, 1982; Philippou, 1986). The moisture problem is endemic to all biomass fuels where $\mathrm{H}_{2} \mathrm{O}$ contents range from 20 to $50 \%$ (M.C. \% on a wet basis) or greater among the municipal waste and crop waste categories (Tillman, 1978; Philippou, 1981). The moisture content significantly influences (reduces) the heating value of biomass fuels according to the formula (Tillman, 1978; Philippou, 1982):

$$
\begin{aligned}
& \mathrm{HVw}=\mathrm{HVd}-(0.0114 \mathrm{HV} \times \mathrm{Mw}) \\
& \mathrm{HVd}=\mathrm{HV}-0.15 \mathrm{M}
\end{aligned}
$$

Where:

$\mathrm{HVw}$ : heating value of wet biomass (kcal/kg of wet biomass);

$\mathrm{HVd}$ : heating value of dry biomass (kcal/kg of dry biomass);

HV : heating value of absolutely dry biomass (kcal $/ \mathrm{kg}$ of dry biomass);

Mw : percentage of moisture on the basis of wet biomass weight (\%);

M : percentage of moisture on the basis of dry biomass weight (\%).

\begin{tabular}{|c|c|c|c|c|c|c|c|}
\hline \multirow[b]{2}{*}{$\begin{array}{c}\text { Composition } \\
\text { (\%) }\end{array}$} & \multicolumn{2}{|c|}{ Wood } & \multirow{2}{*}{$\begin{array}{l}\text { Bark } \\
\text { Soft } \\
\text { woods }\end{array}$} & \multirow[b]{2}{*}{ Charcoal } & \multirow[b]{2}{*}{$\begin{array}{c}\text { Pyrolytic } \\
\text { oil }\end{array}$} & \multirow[b]{2}{*}{ Pit-coal } & \multirow[b]{2}{*}{ Crude oil } \\
\hline & $\begin{array}{c}\text { hard } \\
\text { woods }\end{array}$ & $\begin{array}{c}\text { soft } \\
\text { woods }\end{array}$ & & & & & \\
\hline C & 49.80 & 50.90 & 52.1 & 80.3 & 88.3 & $55-74$ & $86-90$ \\
\hline $\mathbf{H}$ & 6.00 & 6.50 & 5.9 & 3.1 & 6.7 & $5.0-6.4$ & $9.5-12$ \\
\hline $\mathbf{O}$ & 43.20 & 41.50 & 38.9 & 11.3 & 40.0 & $3.4-7.0$ & - \\
\hline $\mathbf{N}$ & 0.40 & 0.10 & 0.2 & 0.2 & 0.1 & $1.0-1.5$ & $0.1-0.5$ \\
\hline S & - & - & - & - & - & $0.4-2.1$ & $0.7-3.5$ \\
\hline Ash & 0.40 & 0.50 & 2.3 & 3.4 & - & $3.3-10.1$ & - \\
\hline Specific gravity & 0.57 & 0.45 & - & - & 1.1 & $0.7-0.8$ & $0.95-0.98$ \\
\hline $\begin{array}{l}\text { Heating values } \\
\text { (kcal/kg) }\end{array}$ & 4,500 & 4,900 & 5,073 & 7,420 & 8,900 & $5,237-7,400$ & $9,680-10,560$ \\
\hline
\end{tabular}

Table 2. Characteristics of various fuels.

Source: Philippou (1981, 1986). 
Concerning ash percentage it could be said that it influences proportionately the heating value. Lastly, heating value of forest biomass (on the basis of biomass volume that is burned) increases as its density increases (Tsoumis and Philippou, 1982; Philippou, 1982).

\section{Advantages and disadvantages of biomass as an energy source}

Biomass as a source of energy has advantages and disadvantages. The main advantages from biomass use are the following (Tsoumis and Philippou, 1982; Hall, 1983; Tsoumis, 1986; Philippou, 1986; Apostolakis et al., 1987; Sooter, 1992):
a. it is renewable;
b. its utilisation can be attained by various conversion methods and by relatively simple technologies;
c. its production and conversion do not create ecological and environmental problems (it does not produce oxides of S, N, Pd etc.);
d. it exists throughout the world;
e. biomass use for energy purposes creates employment.

The drawbacks which are related to biomass use are the following (Tsoumis and Philippou, 1982; Hall, 1983; Tsoumis, 1986; Philippou, 1986; Apostolakis et al., 1987; Sooter, 1992):
a. its low conversion efficiency;
b. land areas are required for its production;
c. its seasonal production and its high dispersion (difficult collection);
d. it occupies a large volume which creates difficulties as far as transportation and storage is concerned;
e. relatively low heating value per unit volume;

By reason of these disadvantages, biomass cost remains, comparatively with oil, high. However, this problem is gradually disappearing because of upward trends in oil prices and the atmospheric pollution which is caused by its combustion (Hall, 1983; Apostolakis et al., 1987; Sooter, 1992).

\section{Energy production methods from biomass}

The potential offered by biomass for solving some of the world's energy problems is widely recognised. The energy in biomass may be realised either by direct use as in combustion or by upgrading into a more valuable and usable fuel. This upgrading may be by biological, chemical or thermal methods to give a solid, liquid or gaseous fuel (Beenackers and Bridgwater, 1989). In other words, the methods of energy biomass conversion are distinguished into biochemical (aerobic fermentation, anaerobic fermentation, alcoholic fermentation) (Apostolakis et al., 1987; Sooter, 1992) and thermochemical ones (direct combustion, pyrolysis, liquefaction, gasification) (Ward, 1983; Soltes, 1983; Beenackers and Bridgwater, 1989).

\section{Conclusion}

It could be said that plants constitute a solar energy conversion system, since this is what photosynthesis is all about. Everything which derives from the process of photosynthesis (biomass) is a potential source of energy. The utilisation of biomass as an energy source is based on heat energy production during its combustion; the solar energy captured and stored by plants is released in the form of heat energy during the biomass combustion. The energy value (calorific value) of forest biomass depends on its chemical composition, existence of extractives, moisture content, ash content and density. Lastly, the upward trends in oil prices and atmospheric pollution which is caused by its combustion, increasingly encourage a wider use of biomass as an energy source. 


\section{Conflict of interest statement}

Authors declare that they have no conflict of interests.

\section{References}

ASTM - American Society for Testing and Materials. Standard definitions of terms relating to wood. Philadelphia: ASTM, 1981.

Apostolakis, M.; Kyritsis, S.; Sooter, H. The energy biomass potential in Greece. Athens: Greek Centre of Productivity, 1987. (in Greek)

Beenackers, A. A. C. M.; Bridgwater, A. V. Gasification and pyrolysis of biomass in Europe. In: Ferrero, G. L.; Maniatis, K.; Buekens, A.; Bridgwater, A. V. (Eds.). Pyrolysis and gasification. Amsterdam: Elsevier Applied Science, 1989. p. 129-155.

Hall, D. O. Biomass for energy - fuels now and in the future. In: Côté, W. A. (Ed.). Biomass utilisation. New York: Plenum Press, 1983. p. 1-22. (NATO ASI Series, Series A: Life Sciences, v. 67).

Philippou, J. L. Conversion of biomass into energy and chemicals by thermolytic methods. In: Margaris, N. S.; Mooney, H. A. (Eds.). Components of productivity of Mediterranean Climate Regions. Basic and applied aspects. The Hague: Dr. W. Junk Publishers, 1981. p. 243-255.

Philippou, J. L. Heating value of various Greek species of forest biomass. Proc. of 1st National Conference on Soft Energy Sources, Institute for Solar Engineering, Thessaloniki, p. BIO 2330, 1982. (in Greek).
Philippou, J. L. Chemistry and chemical technology of wood. Thessaloniki: Aristotelian University, 1986. (in Greek)

Soltes, E. D. J. Thermochemical routes to chemicals, fuels and energy from forestry and agricultural residues. In: Côté, W. A. (Ed.). Biomass utilisation. New York: Plenum Press, 1983. p. 537-552. (NATO ASI Series, Series A: Life Sciences, v. 67).

Sooter, H. Biomass and its energy utilisation. Athens: Centre for Renewable Energy Sources (CRES), 1992. (in Greek).

Tillman, D. A. Wood as an energy resource. New York: Academic Press, 1978.

Tsoumis, G. T.; Philippou, J. L. Wood as a renewable energy source. Proc. of 1st National Conference on Soft Energy Sources, Institute for Solar Engineering, Thessaloniki, p. BIO 31 40, 1982. (in Greek).

Tsoumis, G. T. Wood science and technology. Thessaloniki: Aristotelian University, 1986. (v. B; Industrial Utilisation). (in Greek).

Ward, R. F. Food, chemical feedstock and energy from Biomass. In: Côté, W. A. (Ed.). Biomass utilisation. New York: Plenum Press, 1983. p. 23-49. (NATO ASI Series, Series A: Life Sciences, v. 67).

License information: This is an open-access article distributed under the terms of the Creative Commons Attribution License, which permits unrestricted use, distribution, and reproduction in any medium, provided the original work is properly cited. 